\title{
Hairy Stalagmites, a new biogenic root speleothem from Botswana
}

\author{
Gerhard C. Du Preez ${ }^{1 *}$, Paolo Forti ${ }^{2}$, Gerhard Jacobs ${ }^{1}$, Anine Jordaan ${ }^{3}$, \\ and Louwrens R. Tiedt ${ }^{3}$
}

${ }^{1}$ Unit for Environmental Sciences and Management, Potchefstroom Campus, North-West University, Private Bag X6001, Potchefstroom 2520, South Africa ${ }^{2}$ Italian Institute of Speleology, Via Zamboni 67, 40126 Bologna, Italy

${ }^{3}$ Laboratory for Electron Microscopy, CRB, North-West University, Potchefstroom, South Africa

\begin{abstract}
Ngamiland in northwestern Botswana hosts the Gcwihaba Caves which present unique subterranean environments and host speleothems never before recorded. Cave atmospheric conditions can be extreme with temperatures as high as $28^{\circ} \mathrm{C}$ and relative humidity nearing 99.9\%. Within Dimapo and Diviner's Caves peculiar root speleothems that we named 'Hairy Stalagmites' were found. These stalagmites are closely associated with the roots of Namaqua fig (Ficus cordata) trees that enter the cave environment in search of water. Pieces of broken stalagmites were sampled from Dimapo Cave for further investigations. Stereo and electron microscopy revealed that the Hairy Stalagmites consist of multiple intertwined tubes created when thin films of $\mathrm{CaCO}_{3}$ are deposited around fine lateral roots. The importance of the roots is substantiated with evidence of calcified epidermal cells, apical meristems and epidermal imprints. The development of these stalagmites starts when roots accumulate on the cave floor in the vicinity of a water drip and a root nest is created to capture the water. From this point the roots grow upwards (positive hydrotropism) allowing the development of the calcite structure, and as $\mathrm{CO}_{2}$ diffusion and evaporation occurs, $\mathrm{CaCO}_{3}$ is deposited. The environmental conditions necessary for the growth of Hairy Stalagmites, as well their developmental mechanism, are discussed and illustrated.
\end{abstract}

Keywords: $\quad$ Botswana; root speleothem; Hairy Stalagmites; Namaqua fig tree; developmental mechanism; scanning electron microscopy

Received 17 June 2014; Revised 14 September 2014; Accepted 7 October 2014

Citation: $\quad$ Du Preez G.C., Forti P., Jacobs G., Jordaan A. \& Tiedt L.R., 2015. Hairy Stalagmites, a new biogenic root speleothem from Botswana. International Journal of Speleology, 44 (1) 37-47. Tampa, FL (USA) ISSN 0392-6672 http://dx.doi.org/10.5038/1827-806X.44.1.4

\section{INTRODUCTION}

The hypothesis that biological interactions may somehow play a role in the deposition of secondary chemicals in caves was first suggested by Beaumont (1676) and was later described by Tournefort (1704). Speleothems were even considered, due to the presence of inner growing layers, as true 'rock plants'. At the end of the $18^{\text {th }}$ and beginning of the $19^{\text {th }}$ centuries, the most common speleothem types were often represented as parts of trees with stalactites as roots, stalagmites and columns as trunks, and helictites as leaves or flowers (Forti, 2001). However, at the beginning of the $20^{\text {th }}$ century, any biogenic involvement in the formation of speleothems was ruled out as a better understanding of the main chemical mechanisms was achieved. Yet, in time, it became evident that micro-organisms may play some role in the formation of speleothems (Hill, 1976), while roots were reported to induce the development of peculiar speleothems such as showerheads and rootsticles
(Hill \& Forti, 1997). Today, it's generally accepted that plants (mainly roots) can passively advance the development of speleothems by enhancing capillary migration of water to structures where evaporation occurs (Forti, 2001). Also, it has recently been shown that microbial communities can actively influence the genesis and development of certain subaqueous and/ or vadose speleothems (Melim et al., 2001; Barton \& Northup, 2007; Dodge-Wan \& Deng Hui Min, 2013).

Roots are the single portion of a tree which may somehow contribute towards speleothem development, however, it is presumably rare in deeper parts of caves since roots generally do not reach depths greater than several metres. Nevertheless, the morphological effects induced by roots over speleothems are evident. The surfaces of roots that enter cave voids may serve as pathways for the flow of seeping water and, if environmental conditions are favourable, the precipitation of $\mathrm{CaCO}_{3}$ (calcium carbonate). This mechanism causes the development of peculiar stalactites and columns with a tilted and 
often anastomosed shape over which several pseudohelictites grow. These speleothems have globally been observed with the same characteristics and are normally called 'rootsicles' (Hill \& Forti, 1997). In wet tropical environments the root apparatus of large trees may become the main driving force for the development of peculiar cone-shaped stalactites known as 'Showerheads', which were first described from Brazilian caves (Lino, 1989) and later observed in many other tropical areas (Hill \& Forti, 1997). Winkelhofer (1975) was the first to describe root stalagmites from sandstone caves in Germany which were later reported from the Czech Republic and other countries of Central Europe and Northern America (Bunnell, 2010; Pavuza \& Cech, 2013). In all of these cases the root stalagmites either developed in the twilight zone or in total darkness. They were described as conical and/or cylindrical dense networks of several coniferous roots that may reach up to $60 \mathrm{~cm}$ in height. The voids that formed within the networks consisted mainly of living terminal roots often coated by symbiotic fungi, and were filled with sandy grains and organic matter; the latter being the product of mucilaginous excretion and/ or decay of the roots. A smaller part of the network was formed by thicker and/or skeletal roots directly linked to the mother tree. Owing to the chemical composition of the host rock, no part of the root stalagmite was covered by a calcite crust.

The developmental mechanism of root stalagmites was initially described by Jenik \& Kopecky (1992). Kopecky \& Jenik (2001) recognized the dripping of water over a sand floor as the fundamental factor allowing for the development of these biogenic speleothems. In fact, only where dripping water impacts a root, do thin new roots grow upwards and towards the water drip (positive hydrotropism). This allows for the development of conical and/or cylindrical root stalagmites of which the height and diameter depends mainly on the energy of the water splashing on them, as well as on the availability of sand grains. Until recently, root stalagmites have globally been discovered in about 40 locations including from the Czech Republic, Poland, Austria, Slovakia, Hungary, Sweden, Spain, South Africa, Australia, and the United States (Mlejnek, 2010). Most of these caves were formed in sandstone or in other non-carbonate rocks (for example granite and gneisses). Root stalagmites were first discovered in a carbonate environment in 1987 during the exploration of Pofaddergat limestone cave (Namibia), of which a written report was only published nine years later by Marais et al. (1996). These root stalagmites developed below dripping points, were typically $20 \mathrm{~cm}$ tall, 3-4 cm wide, and consisted of densely packed thin rootlets. However, the presence of calcite incrustations was not reported. A few other limestone (or marble) caves (Bunnell, 2010) also host root stalagmites of which only one or two are partially covered by thin calcite crusts (Pavuza \& Cech, 2013). Nevertheless, the organic component of the stalagmites is by far the most dominant.

Peculiar root stalagmites, called Hairy Stalagmites due to the fineness of their roots, have recently been discovered in dolomite caves in Botswana. These root stalagmites are peculiar since they are almost entirely composed of calcite with roots only visible on top of still-active growing speleothems. In the present paper the microclimate of the relevant cave, the morphology and chemical composition of the Hairy Stalagmites, as well as the proposed mechanism responsible for the development of this new type of root stalagmite, are discussed.

\section{GEOLOGICAL SETTING AND CHARACTERISTICS OF STUDY AREA}

\section{Ngamiland: Botswana's host of subterranean realms}

The Gcwihaba Caves, first explored in 1932 by Marthinus Drotsky and initially known as Drotsky's Caverns, are located in Ngamiland in the northwestern part of Botswana (Cooke, 1975). These caverns have facilitated various scientific expeditions, including paleoclimatic (Cooke, 1975; Railsback et al., 1994), paleontological (Robbins et al., 1996) and mineralogical (Martini, 1996) studies, but have, however, only been visited by a small number of tourists. Subsequently, the government of Botswana initiated the Gcwihaba Caves Project which aims at discovering new cave systems for the purpose of establishing an economically viable tourist destination. As part of the project, ground gravimetric surveys were conducted in order to identify cavities isolated below surface. Entry into these cavities was gained by drilling $600 \mathrm{~mm}$ diameter vertical shafts that penetrate on average $50 \mathrm{~m}$ below surface (Ellis, 2011). Until the beginning of 2014, five new caves have been penetrated of which three are extensive systems. Within two of these systems, Dimapo (20¹'12.34" S, 21 $21^{\circ}$ '38.41” E) and Diviner's (208'32.20” S, 2112'36.60” E) caves, Hairy Stalagmites were discovered.

Diviner's and Dimapo caves are located in the Koanaka and Gcwihaba Hills respectively; both hills form part of the Koanaka Group stratigraphy (Key \& Ayres, 2000; Ellis, 2011). The latter is located in the Precambrian Damara Sequence of Ngamiland (Carney et al., 1994; Williams et al., 2012) and consists of greenschist-facies marble (Singletary et al., 2003). The surface landscape forms part of the Kalahari Desert which is classified as a semi-arid region with shrub savannah vegetation. Rainfall in the desert varies from $400 \mathrm{~mm}$ to $450 \mathrm{~mm}$ per annum and temperatures from $-8.5^{\circ} \mathrm{C}$ to $42.2^{\circ} \mathrm{C}$ (Kennedy et al., 2012). Namaqua fig (Ficus cordata) trees naturally occur in the region, however, are mainly associated with the named hills. Preliminary field investigations have revealed that the trees found on Koanaka Hill directly overly Diviner's and Mongongo $\left(20^{\circ} 8^{\prime} 47.05^{\prime} \mathrm{S}, 2^{\circ} 12^{\prime} 27.08^{\prime} \mathrm{E}\right)$ caves. It is perceived that the specific location of the trees holds relation to their usage of the subterranean cavities as a water source, thus, ensuring their survival in the desert. Fig tree roots have been reported at a maximum depth of 120 meters below surface in Echo Caves (Ohrigstad, South Africa) (Kutschera, 1991). 


\section{Characteristics and features of Dimapo Cave}

Dimapo Cave developed along a fault line as shallow as 40 meters below surface, and represents the main system where Hairy Stalagmites were sampled and studied. As illustrated by Fig. 1, the system is characterized by vast chambers, arrays of parallel passages, flowstone formations such as 'Calcite Mountain' (Fig. 2), slopes of infiltrating Kalahari sands, and extensive boulder fields. Dimapo Cave, as well as the other drilled caves, present microclimates atypical to southern Africa's caves. Durand et al. (2012) reported average temperatures of $17^{\circ} \mathrm{C}$ in the Bakwena

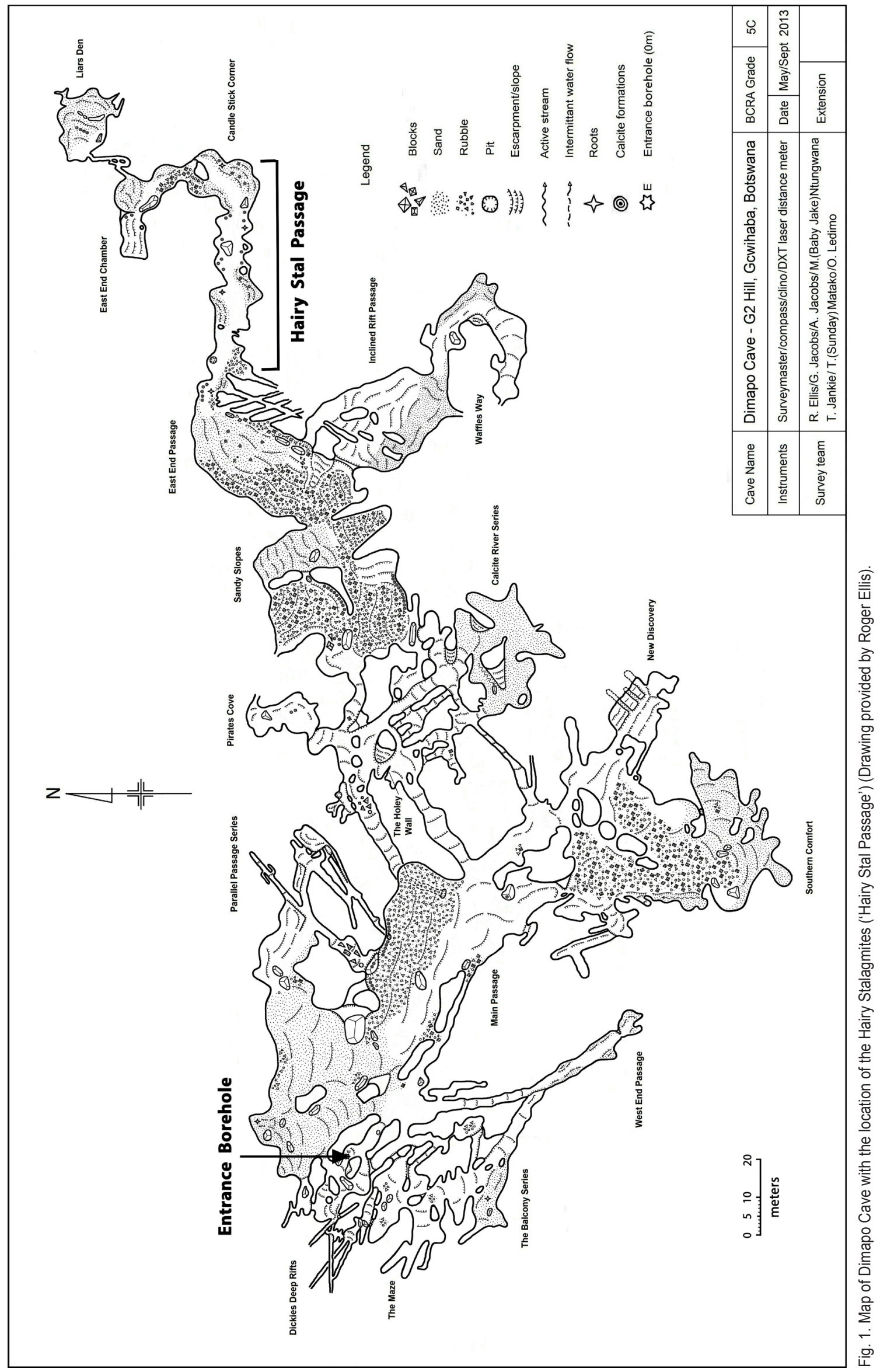




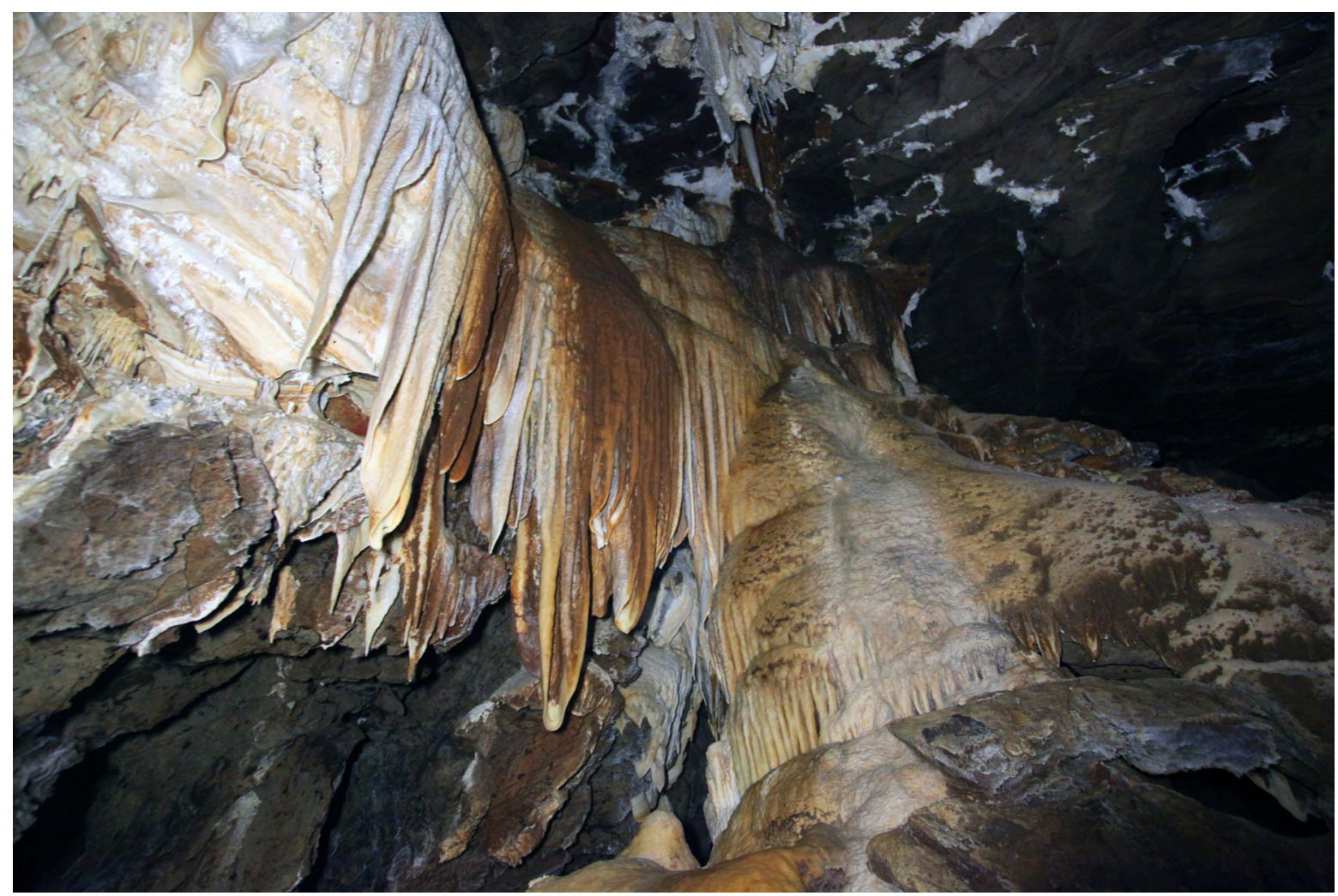

Fig. 2. A flowstone formation referred to as 'Calcite Mountain' in Dimapo Cave (Photo by Anton Jacobs).

Cave (Irene, South Africa). However, temperatures within the drilled caves (Botswana) can reach as high as $28^{\circ} \mathrm{C}$ with $99 \%$ relative humidity, which nears $99.9 \%$ in boulder areas associated with Hairy Stalagmites. It is believed that the Namaqua fig trees utilize the subterranean environment, mainly due to the high humidity levels that result in water flowing along the roots. However, there are numerous water drips throughout Dimapo Cave, which are 'hunted' by roots extending over the cave floor. These roots, in association with the respective water drips, facilitate the development of the Hairy Stalagmites.

The Hairy Stalagmites are found within Dimapo Cave at the northeastern end of the cave system; a 10 to $15 \mathrm{~m}$ wide passage known as 'Hairy Stal Passage' (Fig. 1) which extends $60 \mathrm{~m}$ in an easterly direction, after which it continues $30 \mathrm{~m}$ north and ends in an alcove. On both sides of the passage are banks of infiltrating sand overlain by roots.

\section{METHODS}

Inactive and partially broken Hairy Stalagmite samples were carefully collected during September (spring) 2013 from Dimapo Cave (Botswana) by using a hand spade. Care was taken to avoid any direct skin contact. The cave atmospheric conditions were measured with a calibrated Vaisala thermo hygrometer (HMI41) which was left undisturbed for 15 minutes to ensure stable and accurate readings. The samples were stored in cushioned plastic containers, sealed, and transported to the NorthWest University (Potchefstroom, South Africa) and University of Bologna (Italy) for further analyses.

During all analyses, samples were handled using latex gloves and stored at room temperature in airtight containers. In order to study the surface features of the speleothem more closely, a Nikon AZ100 (Amsterdam, Netherlands) stereo microscope and FEI Quanta 250 FEG (Bruno, Czech Republic) scanning electron microscope (SEM) with integrated software was used. Stereo light micrographs were taken with a digital camera by making use of the Nikon NIS-Elements software package that creates multilayered-image micrographs. For SEM, smaller pieces of speleothem were sputter-coated with gold/ palladium. A small piece of uncoated Hairy Stalagmite was used to analyse the chemical composition of the speleothem substrate with energy-dispersive spectroscopy (EDS) by using an Oxford X-max 20 SDD detector and INCA software.

\section{RESULTS AND DISCUSSION}

\section{The Hairy Stalagmites}

Most of the Hairy Stalagmites found in Dimapo Cave are 'dead' (Fig. 3); calcite deposition has ceased most likely due to climatic variability and is indicated by the absence of Namaqua fig tree roots associated with the structure of the speleothems. It was noted that more than $90 \%$ of the speleothems were stagnant, however, some were 'alive', as roots were directly associated and intertwined with their structure (Fig. 4). Typically, roots travel along the cave strata and where intercepted by a water drip, give rise to many smaller rootlets and root hairs; an interconnected web of roots is created which plays a vital role in the development of the speleothem. The dimensions of the different Hairy Stalagmites vary greatly; some are only a few centimetres tall, while others tower over one meter. Generally, the Hairy Stalagmites are three to five centimetres in diameter. The latter, as well as the speed of growth 
of the speleothems, is most likely affected by: (1) the sustainability and volume of the water source, (2) the concentration of dissolved $\mathrm{CaCO}_{3}$, and (3) the kinetic energy locked within each water drop. The amount of kinetic energy, determined by the distance of travel and diameter of a water drop, affects the dispersion of

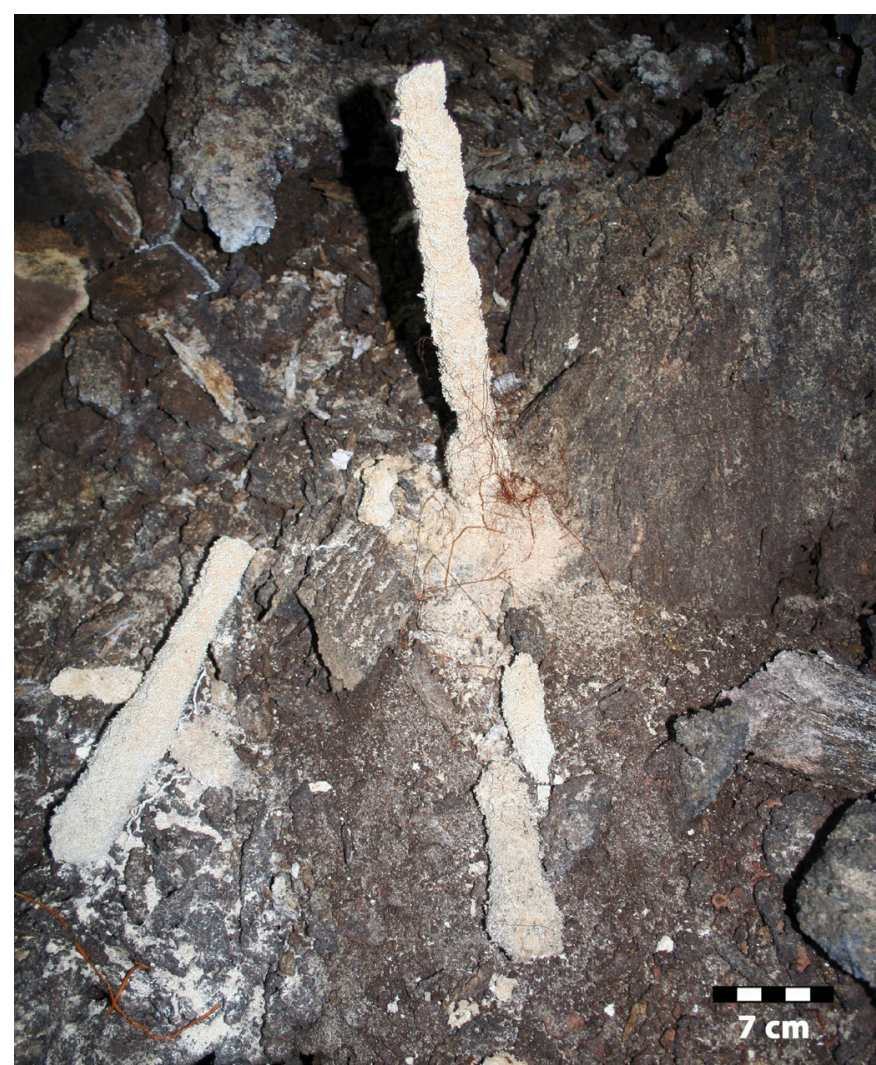

Fig. 3. A 'dead' Hairy Stalagmite that has collapsed and regrown over time with roots associated with the base of the speleothem.

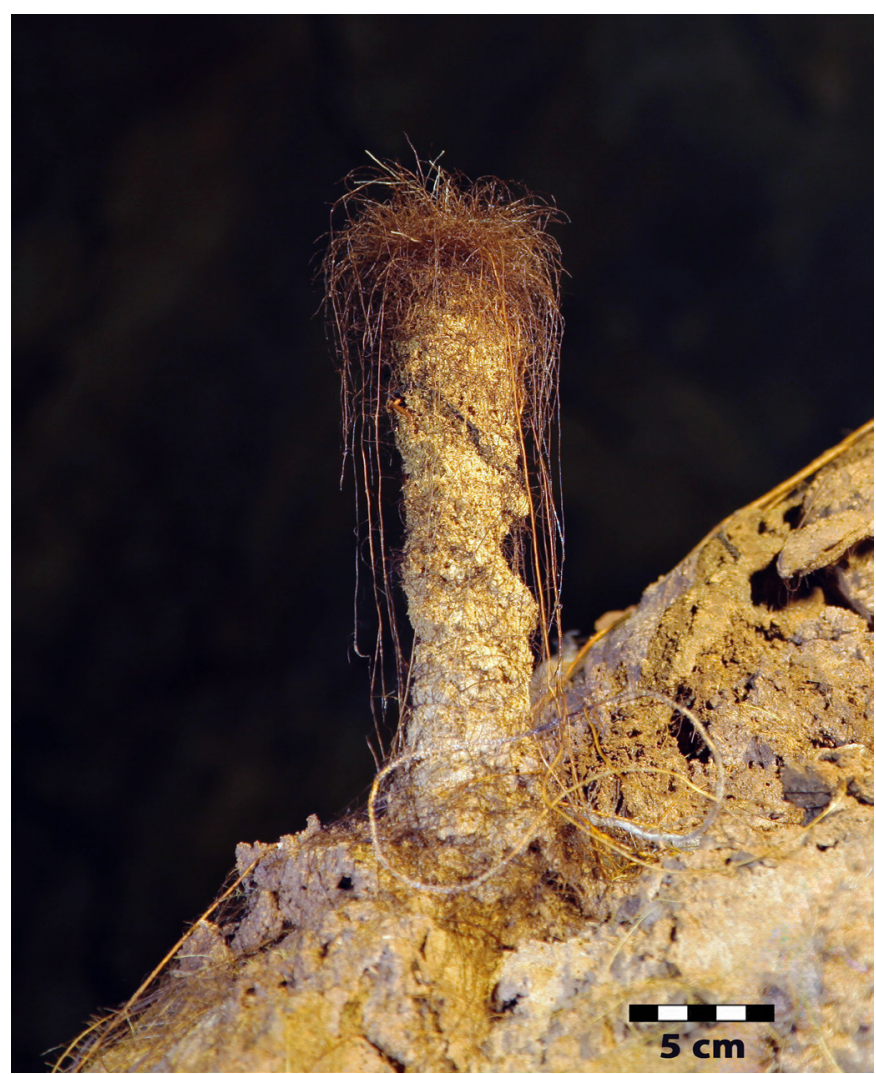

Fig. 4. Namaqua fig tree roots associated with an active Hairy Stalagmite. The roots create a nest at the top of the speleothem which captures the water from the drip (Photo by Anton Jacobs). it upon impact (Salles et al., 2002) and thus possibly the initial base thickness of the speleothem.

\section{Microscopy investigations}

Multilayered-imaging micrographs revealed that the entire structure consists of multiple intertwined tubes (Fig. 5). The tubes were initially formed around a network of lateral roots that originated from several horizontally-growing roots on the cave floor. The initial Hairy Stalagmites, also referred to as nests, consist of a network of modified roots that grow upwards. Lamont \& Lange (1976) referred to them as stalagmiform roots.

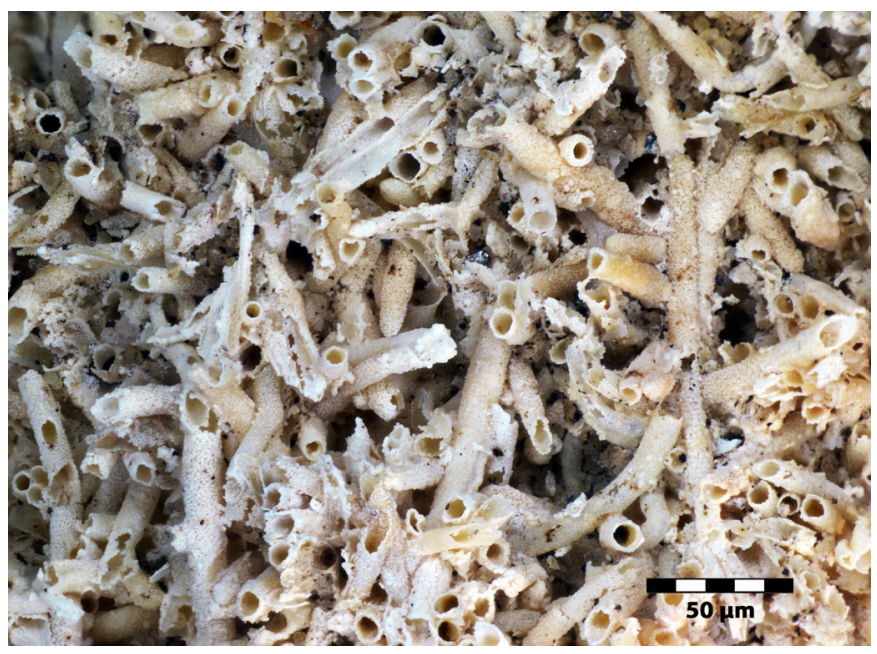

Fig. 5. Micrograph of the external surface of a Hairy Stalagmite illustrating the intertwined calcite tubes that constitute its structure.

The individual tubes were studied more closely with the SEM. The inner surfaces of the calcite tubes showed the presence of both calcified epidermal cells, as well as epidermal root imprints (Fig. 6) that were sporadically found in close proximity to one another. Rarely, entire calcified root fragments (Fig. 7) were observed inside the Hairy Stalagmites. Intact calcified cells in the tubes were mostly root apical meristems (Fig. 8). Root caps appeared to be well preserved as their anatomical attributes were clearly visible as a population of thin-walled, isodiametrically-shaped cells (Fig. 8). The coarse granular texture of the root tips points to the calcification of a mucilaginous substance called mucigel that is normally secreted by root cap cells. Further back from the root tip, root imprints were predominantly observed and only occasionally intact calcified epidermal cells. In root fragments there was no evidence of calcified cortex cells, but the epidermis appeared to be multiseriate and the cell layer underneath the outermost epidermal layer was also calcified (Fig. 7). A cross section (Figs. 9; 10) revealed that no organic matter remains within the tubes because of the complete decomposition of dead roots. This process is important for nutrient recycling as it constantly makes nutrients available for new root growth and has important implications for the maintenance of the cave and above-ground ecosystem.

A possible explanation for the presence of both replicas and calcified cells is that some roots were alive when calcification occurred, while others were already dead. Calcified cells point towards rapid $\mathrm{CaCO}_{3}$ 
biomineralization while the roots were still alive. Replicas are the consequence of physical precipitation of calcite around already dead roots. The dead roots subsequently disintegrate and leave epidermal imprints on the calcite. The presence of both types of rhizoliths may highlight the role of the root itself in the calcite deposition process. Living, respiring roots add $\mathrm{CO}_{2}$ to their surroundings, which may produce $\mathrm{H}_{2} \mathrm{CO}_{3}$ in the presence of $\mathrm{H}_{2} \mathrm{O}$. Subsequently, higher acidity levels will produce a carbonate rich solution. This solution may penetrate intercellularly and also impregnate cell walls. As the calcite reprecipitates, it effectively preserves cell structure relatively quickly.

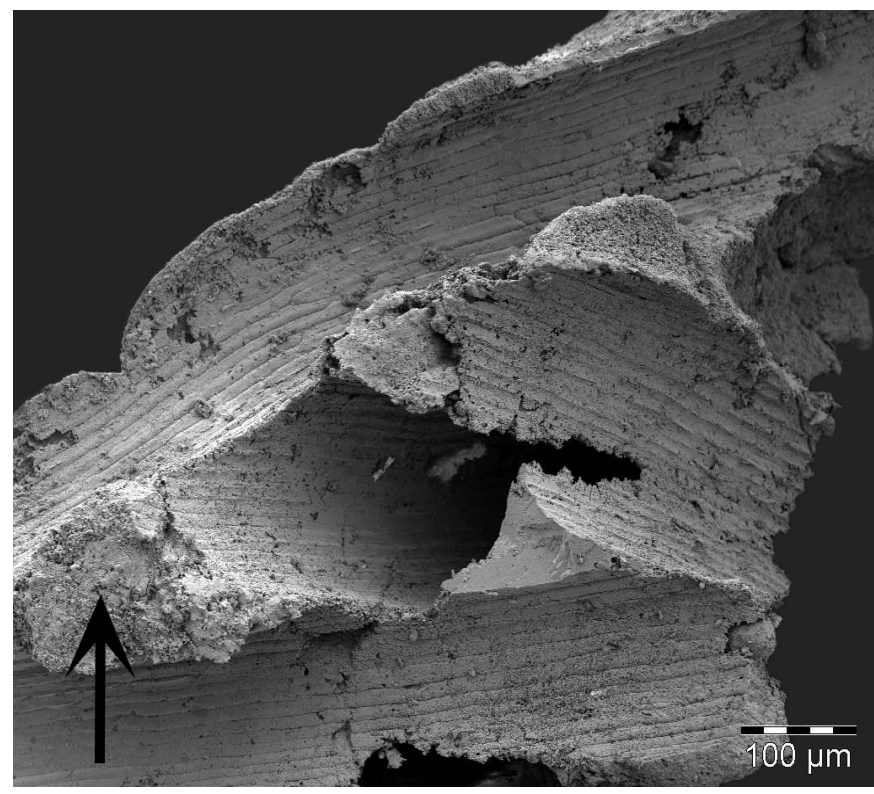

Fig. 6. Scanning electron micrograph showing root epidermal cell imprints created as $\mathrm{CaCO}_{3}$ was deposited over the roots. Inter-tube cavities are sometimes partially filled with calcite (arrow).

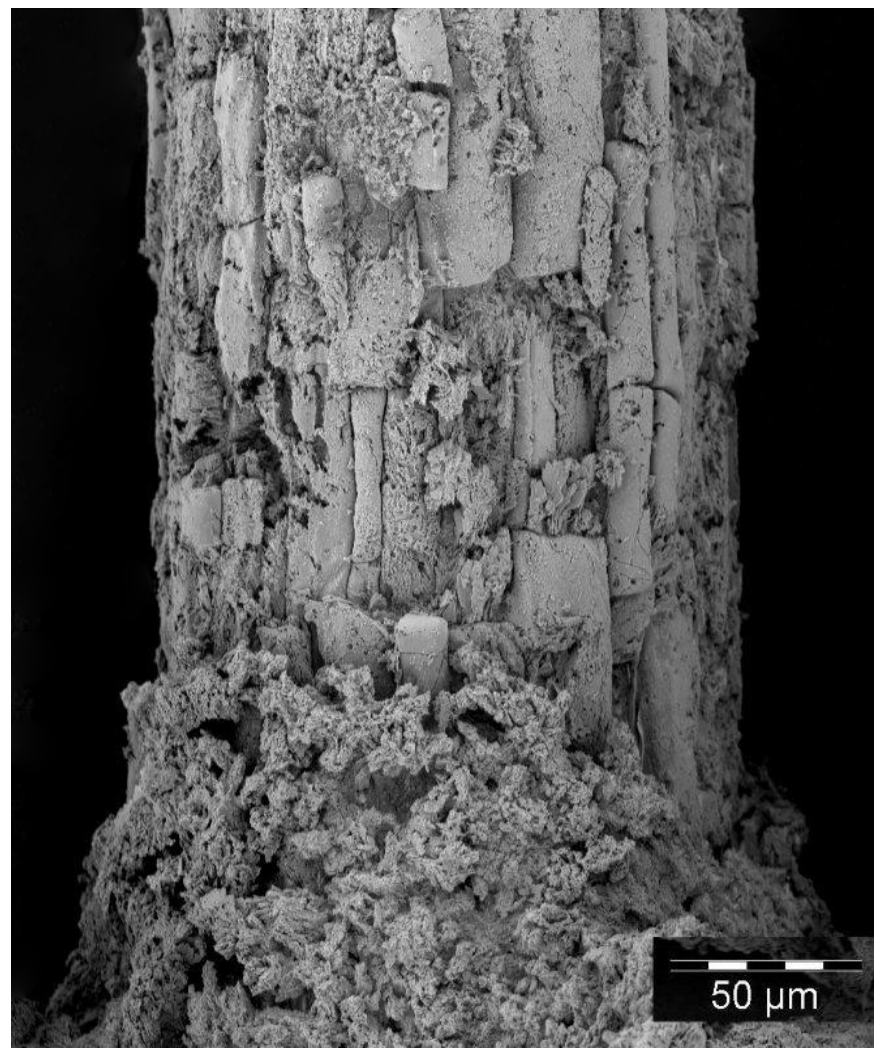

Fig. 7. Scanning electron micrograph showing intact calcified root fragment with calcite partially surrounding the bottom part of it.

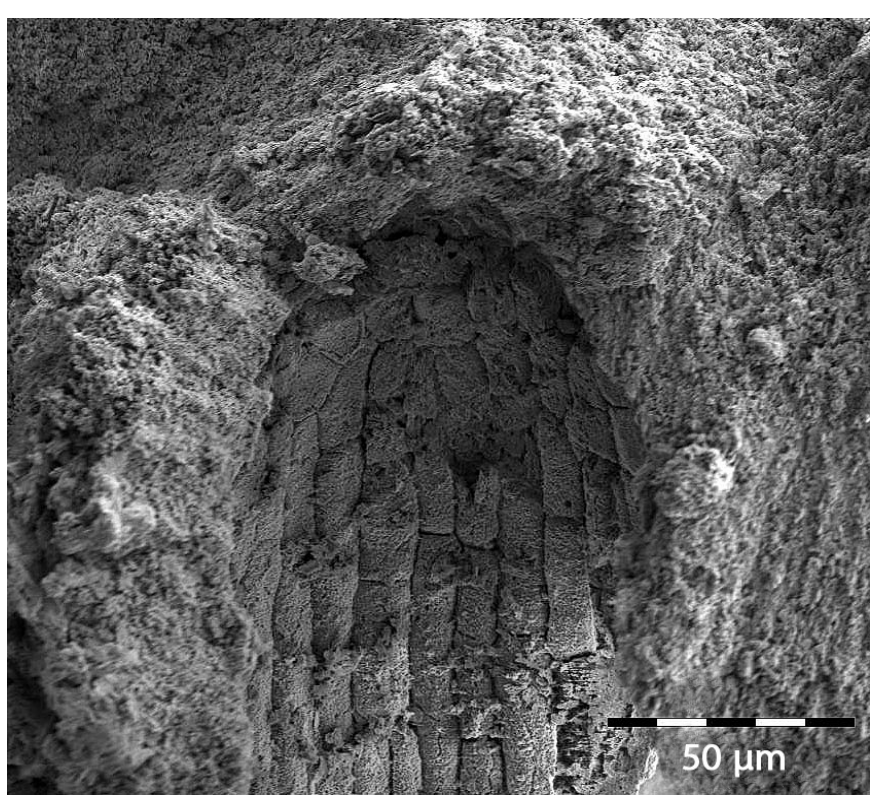

Fig. 8. Scanning electron micrograph showing root tip that contains calcified and isodiametrically-shaped thin-walled root cap cells and young epidermal cells in the zone of cell division.

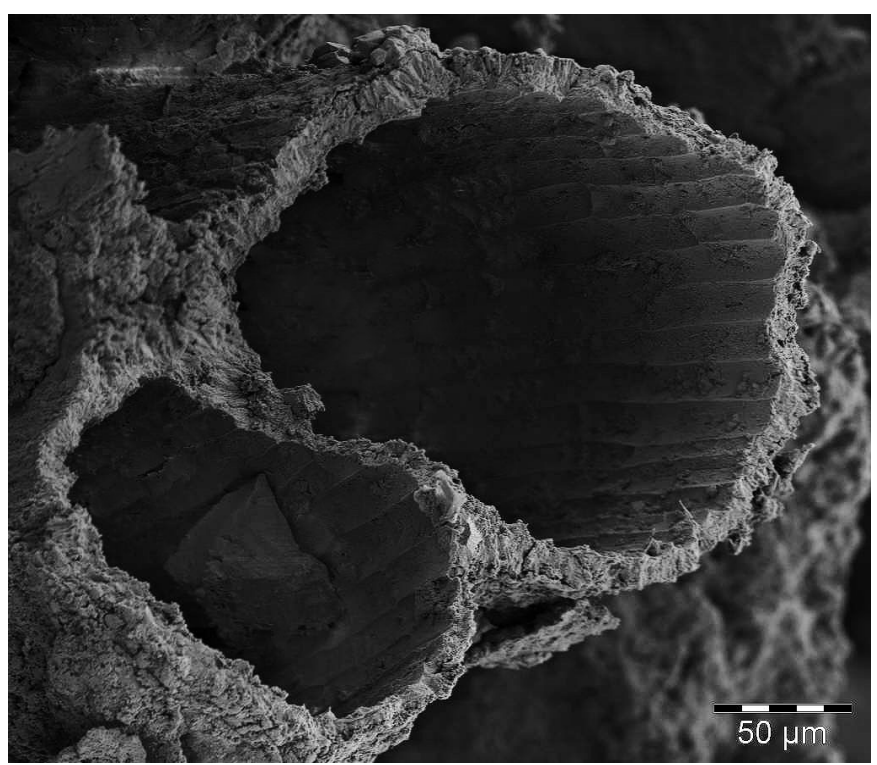

Fig. 10. Scanning electron micrograph of a cross section through calcite tubes shows that no organic matter remains within the tubes.

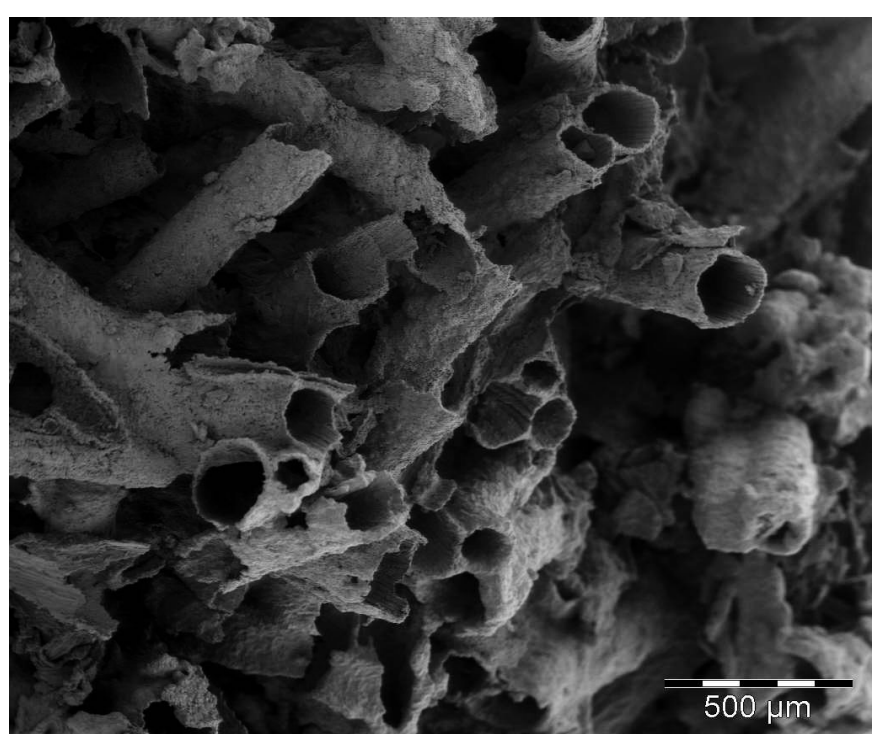

Fig. 9. Scanning electron micrograph of a cross section of multiple calcite tubes showing that all organic matter has either been decomposed or calcified. 
However, water removal through absorption by mature living roots may concentrate the carbonate solution and also contribute to $\mathrm{CaCO}_{3}$ precipitation, but mostly to the formation of calcite tubes surrounding the roots. Since there is no or limited impregnation and reprecipitation of cell walls and intercellular spaces by the carbonate solution, only epidermal imprints are left after the decomposition of organic material. The zone of cell division in the root tip consists of a population of actively dividing cells and hence high respiration rates. The more common preservation of the root cap cells in root tips, rather than older cells in mature root regions, points to the role of $\mathrm{CO}_{2}$ from respiring roots during calcifications of cell structures. However, although biogenic processes may be involved in the calcification of some cells, it is probably a less dominant process than the physical processes involved during the precipitation of $\mathrm{CaCO}_{3}$ around individual roots. The calcified tube walls are thin $(10-20 \mu \mathrm{m})$ which indicates an overall slow rate of precipitation around each root. The EDS analysis (47.8\% $\mathrm{CaO}, 3.8 \% \mathrm{MgO}, 0.7 \% \mathrm{SiO}_{2}$, and $47.8 \% \mathrm{CO}_{2}$ ) revealed that the tubes consist of more than $95 \%$ of $\mathrm{CaCO}_{3}$.

\section{The developmental mechanism of a Hairy Stalagmite}

When considering the development of a Hairy Stalagmite, several conditions are necessary for both the deposition of calcite, as well as the calcification of roots. The following conditions, however, are generally required for the development of any root stalagmite:

1. Trees and/or bushes of which the roots are capable of penetrating the underlying cave must cover the aboveground landscape. Thus, the depth of cave development may not exceed the limit of root penetration.

2. The cave environment must serve as a sufficient and sustainable water source.

3. Dripping water should contain dissolved $\mathrm{CaCO}_{3}$.

4. Dripping inside the cave must be constant and provide sufficient water to avoid the desiccation of the roots, however, the cave floor must remain dry enough to induce positive root hydrotropism.

The following additional and specific conditions are required for the development of a Hairy Stalagmite:

5. Dripping water must either be slightly undersaturated or slightly oversaturated with $\mathrm{CaCO}_{3}$. This is required to facilitate the development of Hairy Stalagmites and not typical speleothems (stalagmites and/or flowstones). If high supersaturation conditions were induced, it would result in rapid calcite deposition, thus burying the roots inside the formed structure.

6. Water flow, as a result of water dripping, should be minimal to allow for the deposition of calcite and to avoid the transport of deposited particles.

7. The relative humidity of the cave atmosphere must remain high in order to prevent the desiccation of the root tips, however, below $100 \%$ to avoid condensation of $\mathrm{CO}_{2}$ rich water over the roots, which will hinder calcite deposition.

8. Dying-off and degradation of the roots associated with the Hairy Stalagmites should be slow enough in order to facilitate adequate calcite deposition and structure forming.

The development of a Hairy Stalagmite can only occur when all of these conditions are met, explaining why these speleothems are a rare phenomenon. The developmental mechanism can be sub-divided into five stages of which a description follows:

Stage one is initiated when roots from the surface penetrate the cave and travel along the cave walls and floor until they reach a constant water dripping point (Figs. $11 \mathrm{~A}$; 12). The water stimulates the growth of several small hydrophilic upwards (positive hydrotropism) growing roots, creating a rounded root nest (Figs. $11 \mathrm{~B}$; 13). As root growth continues, the nest enlarges, while the impact of the droplets creates a deepening depression in the center. The concave shape of the nest and its increasing central depth progressively reduce the impact of the water drops, which subsequently prevents droplets from escaping it. The lateral expansion of the nest stops when all of the dripping water is contained within it. Furthermore, the lateral roots facilitate capillary migration of water towards the external part of the nest where calcite deposition processes are active. Nearing the end of this stage, most, if not all of the droplets, are kept within the root nest, which is substantiated by the absence of calcite deposition in the form of layered structures over the external surface or around the base of the stalagmite.

During the second stage (Fig. $11 \mathrm{C}$ ), the rounded root nest with a central depression captures and disperses water by capillary action throughout the nest. Supersaturation of $\mathrm{CaCO}_{3}$ is possibly induced by several different reactions. Within this peculiar micro-environment, $\mathrm{CO}_{2}$ diffusion and $\mathrm{H}_{2} \mathrm{O}$ evaporation may not be the only mechanisms involved in calcite deposition, especially since the high relative humidity and $\mathrm{CO}_{2}$ partial pressure of the cave atmosphere will inhibit these processes. Other biologically driven mechanisms, including selective water uptake by roots through a biological film (Klappa, 1980) and mineralizing microbial colonies within the biological film around the roots (Cacchio et al., 2012), may also facilitate the deposition of a thin layer of calcite around the roots, thus, creating calcite tubes (Fig. 11 D). The force of the water drops impacting the structure causes the partial detachment of some of the newly formed calcite crust. The detached calcite grains accumulate on the cave floor along the perimeter of the nest. A conical-shaped sandy deposit is formed, becomes enlarged and hardened, and ultimately serves as a protection barrier that prevents the detachment of the thin calcite layers from the individual lateral roots. Calcite deposition continues towards the core of the nest, covering new roots, thickening calcite films surrounding others, and fuses the root structures together, while also partially filling inter-tube cavities (Fig. 6). Since water is constantly introduced at the center of the nest, 
supersaturation of $\mathrm{CaCO}_{3}$ and thus calcite deposition is significantly inhibited. This, together with the impact force of the water drops, causes the core structure to be weaker than the rest of the stalagmite.

In the third stage a true Hairy Stalagmite is formed (Figs. $11 \mathrm{E}$; 4), characterized by a constant external diameter and vertically growing roots near the core. The calcite films inhibit the growth of the roots by clogging the vascular system, which prevents the roots from conducting water and food. This ultimately leads to the death of most of the roots. However, since the external diameter of the stalagmite remains relatively constant, it is evident that the roots die-off at a specific rate as root lifespan and radial growth is inhibited by the calcification process. After the organic matter has decomposed, the remaining calcite films
(10-20 $\mu \mathrm{m}$ thickness) become an intricate network of interconnected hollow tubes (Fig. 10). Some root epidermal cells and root tips are calcified (Figs. 7; 8), while other roots have died before any calcification could take place, as only root surface imprints are visible inside the calcite tubes (Fig. 6).

The described process of Hairy Stalagmite formation may last for several years, creating speleothems over $1 \mathrm{~m}$ tall. Discontinuities visible as indentations in the external diameter (Fig. $11 \mathrm{~F}$ ) are most likely induced by the reduced frequency of dripping during the dry season, which will also lower the relative humidity of the cave atmosphere. Thus, $\mathrm{H}_{2} \mathrm{O}$ uptake by roots, evaporation, and $\mathrm{CO}_{2}$ diffusion are enhanced close to the external surface (Fig. $11 \mathrm{~F} 1$ ). These combined processes are also responsible for the deposition of
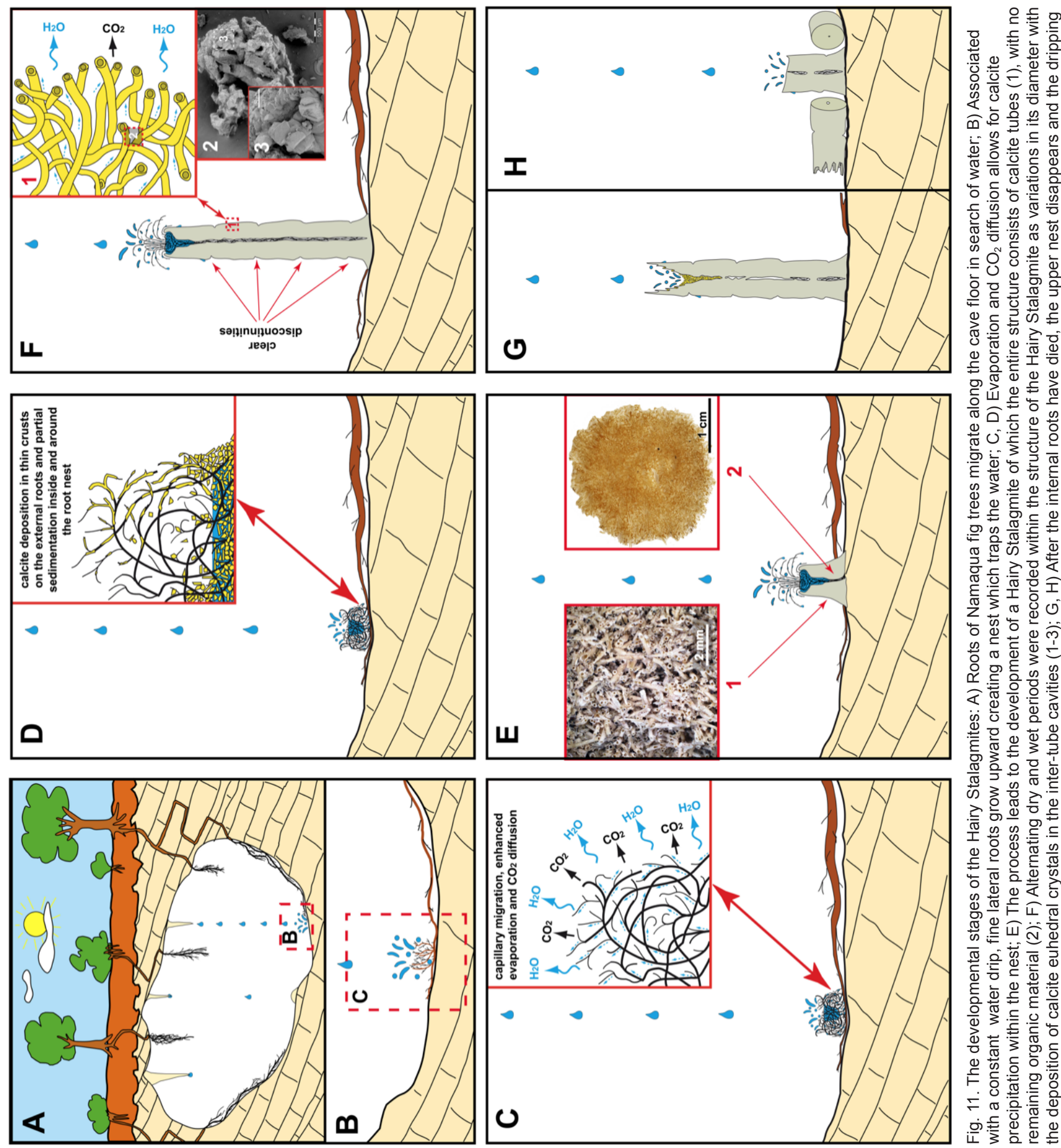

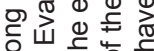

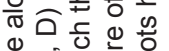

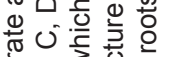

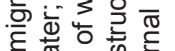

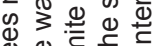

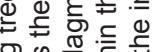

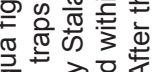

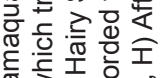

经过

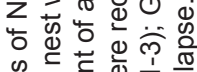

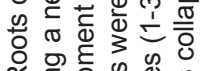

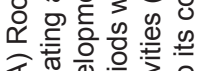

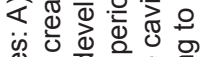

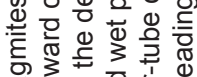

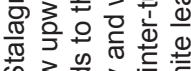

क

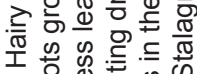

工

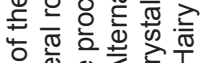

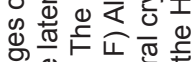

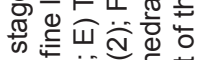

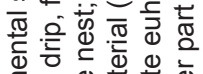

है

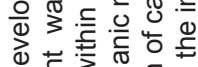

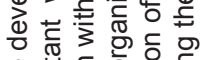

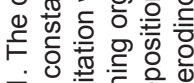

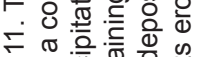

두을 


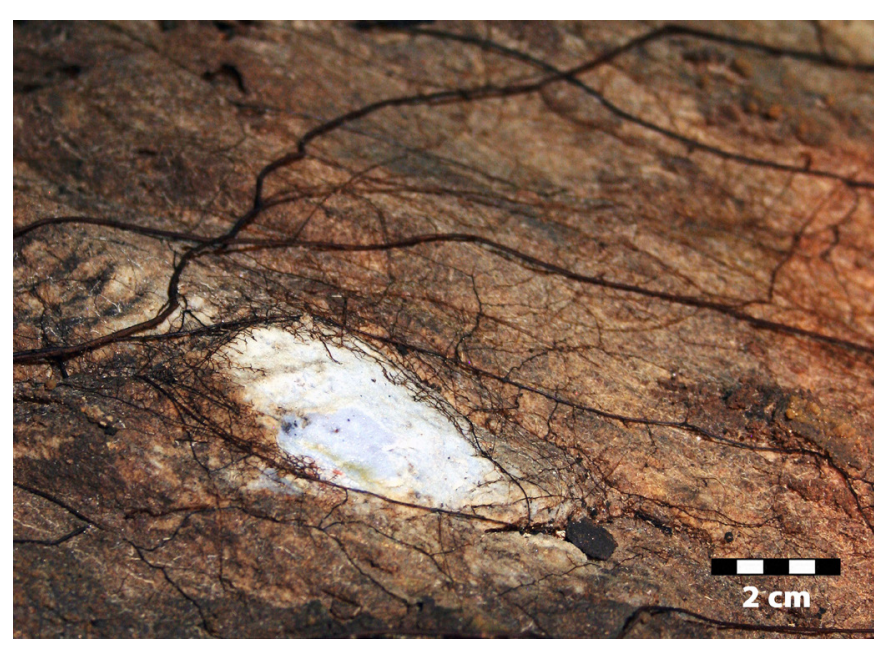

Fig. 12. Dripping point on the cave floor 'hunted' by roots, which marks the start of the development of a Hairy Stalagmite.

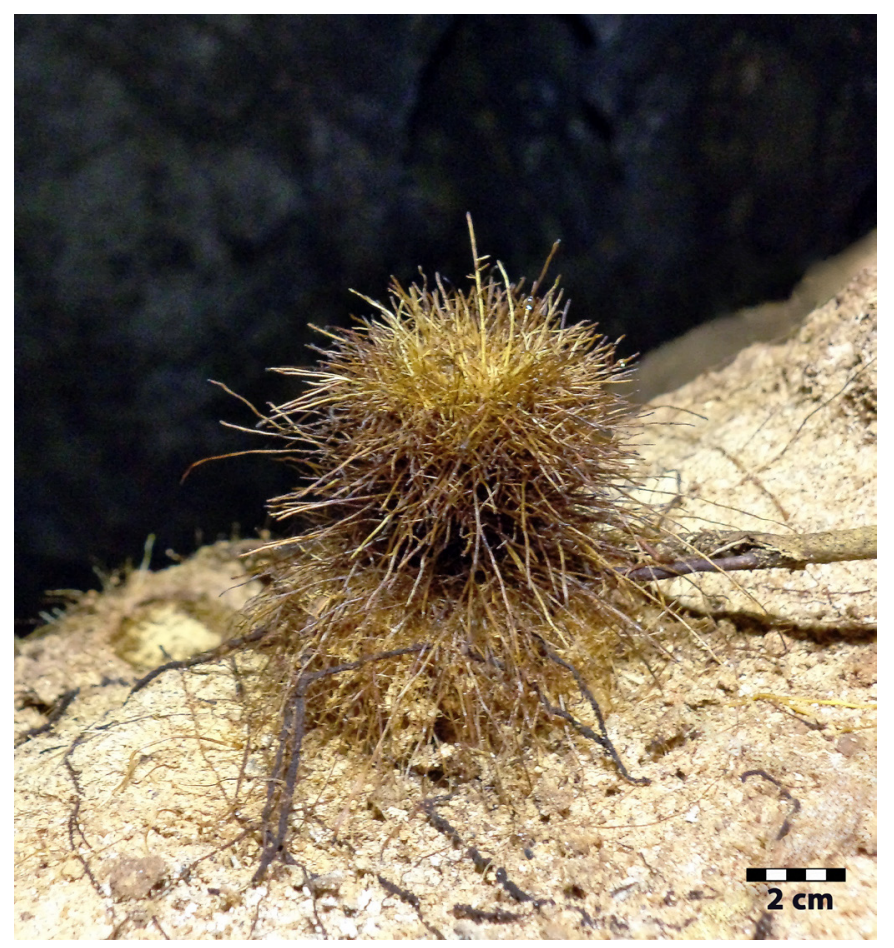

Fig. 13. Root nest created during the first stage of development of a Hairy Stalagmite.

calcite crystals (Fig. 11 F2-3) in the voids that exist between the formed calcite tubes. While the calcite linings over the roots consist of small elongated crystals with a highly porous structure, the calcite deposited in the inter-tube cavities and on the surface of the Hairy Stalagmites has an entirely different morphology. The former is the result of alternating deposition and re-dissolution of calcite most likely controlled by biogenic processes that subsequently give rise to a high amount of $\mathrm{CO}_{2}$. On the contrary, the calcite in the cavities and on the surface of the Hairy Stalagmite consist of euhedral non-porous crystals (Figs. 14; 15) which suggests a slow but continuous deposition process controlled by evaporation and/or enhanced $\mathrm{H}_{2} \mathrm{O}$ uptake by roots during the dry season. As a result, the external surface of the stalagmite is more hardened. Due to the above described process, only the roots growing vertically along the dripping line survive. However, as they reach the open space above the partially hardened nest, they create an elaborate umbrella structure (Fig. 4) which allows the further development of the Hairy Stalagmite.

The fourth stage (Fig. $11 \mathrm{G}$ ) is related to the decay of the Hairy Stalagmite, which is influenced by the availability of water, the rate of calcite hardening, and the height of the structure. As the Hairy Stalagmite becomes taller, the roots within the structure may break as they become more fragile and exposed especially during the dry season. Also, if water dripping ceased for a period of time, the roots may become petrified. Consequently, the root nest at the top of the stalagmite will die and disintegrate, leaving the stalagmite exposed to the impact of dripping water. Direct contact between the water drops and the calcite structure will progressively degrade it and block the tubes with calcite fragments.

Finally, during the fifth stage (Fig. $11 \mathrm{H}$ ), the Hairy Stalagmites become unstable without the support of living roots. Furthermore, the impact of falling water drops is no longer cushioned by the root nest. If enough force is generated, the Hairy Stalagmite may break and collapse (Fig. 3), most likely at an area of weakness closer to the base of the speleothem. An area of weakness is probably the result of incomplete calcification and may also explain the discontinuities (Fig. $11 \mathrm{~F}$ ) that were observed in the external diameter of the stalagmite. If conditions again become favorable, the portion of the Hairy Stalagmite left standing may be recolonized by roots. This marks the start of the development of a new Hairy Stalagmite continuing from the third stage.

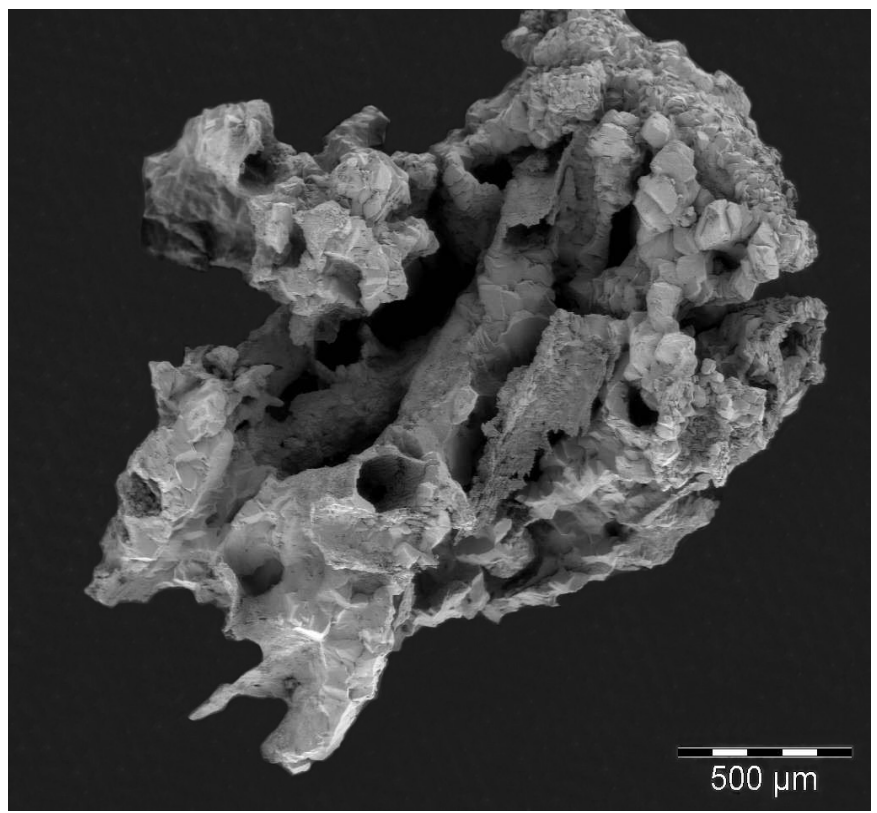

Fig. 14. Scanning electron micrograph showing euhedral calcite crystals that formed near the surface of a Hairy Stalagmite.

\section{FINAL REMARKS}

Hairy Stalagmites, a new type of biogenic speleothem, consist of both calcite tubes and calcified root cells, and are peculiar specimens representing biogenicallyformed speleothems. Their development is strongly controlled by an intricate set of both atmospheric and abiotic conditions, most likely sensitive to 


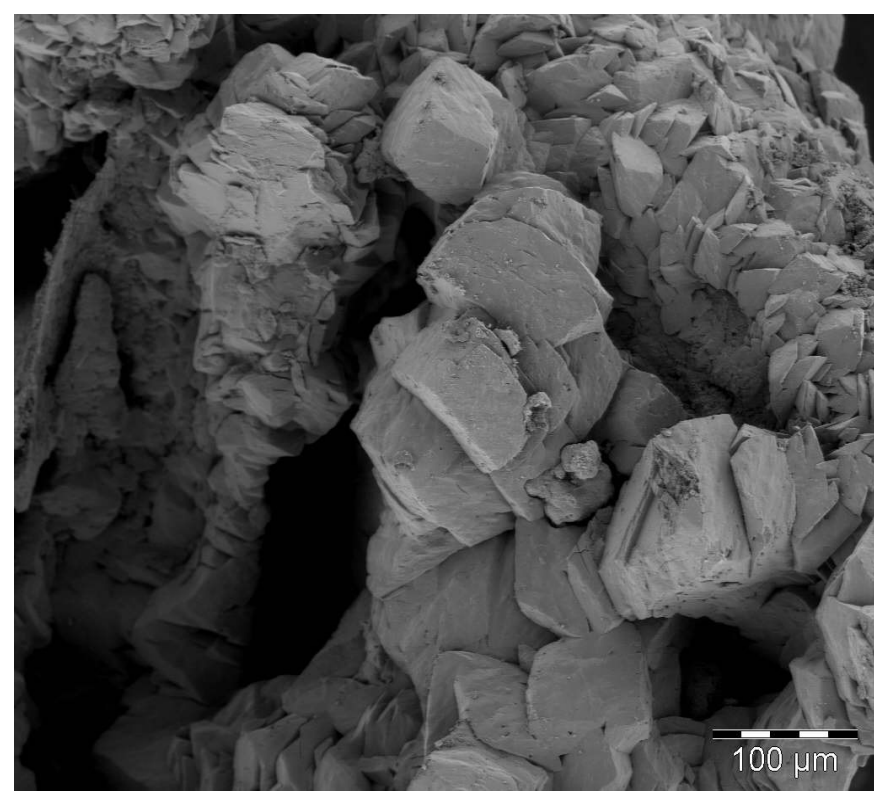

Fig. 15. Close-up view of calcite crystals formed on a Hairy Stalagmite.

climatic variations. The required conditions explain why the Hairy Stalagmites have only been observed in caves previously sealed. In order to preserve this unique environment together with this new type of speleothem, it is necessary to conserve not only the cave atmospheric conditions, but also the surface landscape that hosts the Namaqua fig trees. Therefore, with the Botswana government's efforts to create a tourist destination, adequate measures should be considered to insure the sustainability and function of the caves and surface landscape.

\section{ACKNOWLEDGMENTS}

The authors thank the government of Botswana and in particular the president, His Excellency Lieutenant General Sir Seretse Khama Ian Kama, for continuous support in exploring the wonders of the Gcwihaba Caves. We also thank the team of cavers, led by Roger Ellis, who tirelessly aided our cause, as well as Louis du Preez for insight provided. Furthermore, we thank the reviewers for their significant contribution by means of actual and relevant commentary.

\section{REFERENCES}

Barton H.A. \& Northup D. E., 2007 - Geomicrobiology in cave environments: past, current and future perspectives. Journal of Cave and Karst Studies, 69 (1): 163-178.

Beaumont J., 1676 - Two letters concerning rockplants and their growth. Philosophical Transactions of the Royal Society, 11 (129): 732-742.

Bunnell D., 2010 - Root stalagmite in a carbonate cave. NSS News July 2010: 28.

Cacchio P., Ercole C., Contento R., Cappuccio G., Martinez M.P., Del Gallo M. \& Lepidi A., 2012 - Involvement of bacteria in the origin of a newly discovered speleothem in the gypsum cave of Grave Grubbo (Crotone, Italy). Journal of Cave and Karst Studies, 74 (1): 7-18.

http://dx.doi.org/10.4311/2010MB0136R

Carney J., Aldiss D. \& Lock N.P., 1994 - The geology of Botswana. Geological Survey Department, Lobatse, 113 p.
Cooke H., 1975 - The palaeoclimatic significance of caves and adjacent landforms in western Ngamiland, Botswana. Geographical Journal, 141 (3): 430-444. http://dx.doi.org/10.2307/1796477

Dodge-Wan D. \& Deng Hui Min A., 2013 - Biologically influenced stalagmites in Niah and Mulu Caves (Sarawak, Malaysia). Acta Carsologica, 42 (1): 155-163. http://dx.doi.org/10.3986/ac.v42i1.634

Durand F., Swart A., Marais W., Jansen van Rensburg C., Habig J., Dippenaar-Schoeman A., Ueckermann E., Jacobs R., De Wet L., Tiedt L. \& Venter E., 2012 - Die karst-ekologie van die Bakwenagrot (Gauteng). SuidAfrikaanse Tydskrif vir Natuurwetenskap en Tegnologie, 31 (1): 1-17.

http://dx.doi.org/10.4102/satnt.v31i1.275

Ellis R., 2011 - Report on the expedition to the Koanaka Hills, Botswana. Cave Exploration Rescue and Adventure Club, Johannesburg, 27 p.

Forti P., 2001 - Biogenic speleothems: an overview. International Journal of Speleology, 30 (1): 39-56.

Hill C.A., 1976 - Cave minerals. National Speleological Society, Huntsville, 138 p.

Hill C.A. \& Forti P., 1997 - Cave minerals of the world. National Speleological Society, Huntsville, 464 p.

Jenik J. \& Kopecky J., 1992 - Korenové stalagmity $v$ piskovcovych jeskynich. Knihovna České speleologické společnosti, 10: 26-34.

Kennedy A.M., Marais J., Bauer A.M., Lewis P.J. \& Thies M.L., 2012 - Effect of fire on the herpetofauna of the Koanaka Hills, Ngamiland, Botswana. Check List, 8 (4): 666-674.

Key R.M. \& Ayres N., 2000 - The 1998 edition of the National Geological Map of Botswana. Journal of African Earth Sciences, 30 (3): 427-451.

http://dx.doi.org/10.1016/S0899-5362(00)00030-0

Klappa C.F., 1980 - Rhizoliths in terrestrial carbonates: classification, recognition, genesis and significance. Sedimentology, 27 (6): 613-629.

http://dx.doi.org/10.1111/j.1365-3091.1980.tb01651.x

Kopecky J. \& Jenik J., 2001 - Root forms from pseudokarst. In: Jubertie C. \& Decu V. (Eds.) - Encyclopaedia Biospeleologica, Tome III. Moulis - Bucharest: Société de Biospéologie: 1420-1421.

Kutschera L., 1991 - Short review of the present state of root research. In: McMichael B.L. \& Persson H. (Eds.) - Plant roots and their environment. Amsterdam: Elsevier: 1-8.

http://dx.doi.org/10.1016/B978-0-444-89104-4.50005-0

Lamont B.B. \& Lange B.J., 1976 - 'Stalagmiform' roots in limestone caves. New Phytologist, 76: 353-360. http://dx.doi.org/10.1111/j.1469-8137.1976. tb01470.x

Lino C.F., 1989 - Cavernas: o fascinante Brazil subterrâneo. Editora Rios, Sao Paulo, 280 p.

Marais J.C.E., Irish J. \& Martini J.E.J., 1996 - Cave investigation in Namibia V: 1993 SWAKNO results. Bulletin of South African Speleological Association, 36: $58-78$.

Martini J.E.J., 1996 - Gwihabaite - $\left(\mathrm{NH}_{4}, \mathrm{~K}\right) \mathrm{NO}_{3}$, orthorombic, a new mineral from Gcwihaba Cave, Botswana. South African Speleological Association Bulletin, 36: 19-21.

Melim L.A., Shinglman K.M., Boston P.J., Northup D.E., Spilde M.N. \& Queen J.M., 2001 - Evidence of microbial involvement in pool finger precipitation, Hidden Cave, New Mexico. Geomicrobiology Journal, 18 (3): 311-329.

Mlejnek R., 2010 - America, look for root stalagmites! NSS News April 2010: 14. 
Pavuza R. \& Cech P., 2013 - Wurzelstalagmiten in Österreich - ein Statusbericht. Die Höhle, 62: 25-31.

Railsback L.B., Brook G.A., Chen J., Kalin R. \& Fleisher C.J., 1994 - Environmental controls on the petrology of a late Holocene speleothem from Botswana with annual layers of aragonite and calcite. Journal of Sedimentary Research, 64 (1): 147-155.

Robbins L., Murphy M.L., Stevens N.J., Brook G.A., Ivester A.H., Haberyan K.A., Klein R.G., Milo R., Stewart K.M., Matthiesen D.G. \& Winkler A.J., 1996 - Paleoenvironment and archaeology of Drotsky's Cave: Western Kalahari Desert, Botswana. Journal of Archaeological Science, 23 (1): 7-22.

http://dx.doi.org/10.1006/jasc.1996.0002

Salles C., Poesen J. \& Sempere-Torres D., 2002 - Kinetic energy of rain and its functional relationship with intensity. Journal of Hydrology, 257 (1): 256-270. http://dx.doi.org/10.1016/S0022-1694(01)00555-8

Shaw T.R., 1997 - Historical introduction. In: Hill C. \& Forti P. (Eds.) - Cave minerals of the world. National Speleological Society, Huntsville, 28-43.
Singletary S.J., Hanson R.E., Martin M.W., Crowley J.L., Bowring S.A., Key R.M., Ramokate L.V., Direng B.B. \& Krol M.A., 2003 - Geochronology of basement rocks in the Kalahari Desert, Botswana, and implications for regional Proterozoic tectonics. Precambrian Research, 121 (1): 47-71.

http://dx.doi.org/10.1016/S0301-9268(02)00201-2

Tournefort J.P., 1704 - Description du labyrinthe du Candie, avec quelques observations sur l'accroissement et sur la génération des pierres. Mémoires de l'Académie Royale des Sciences: 406-424.

Williams B.A., Ross C.F., Frost S.R., Waddle D.M., Gabadirwe M. \& Brook G.A., 2012 - Fossil Papio cranium from !Ncumtsa (Koanaka) Hills, western Ngamiland, Botswana. American Journal of Physical Anthropology, 149 (1): 1-17.

http://dx.doi.org/10.1002/ajpa.22093

WinkelhoferR., 1975-Stalagmitenförmige Wurzelbindungen in Sandsteinhöhlen. Der Höhlenforscher, 7 (2): 25-26. 